\title{
New Trends in Developing Alternative Ways to Resolve Financial Disputes
}

\author{
Ermakova Elena Petrovna ${ }^{1}$, Frolova Evgenia Evgenevna ${ }^{1,2,3}$ \& Sitkareva Elena Vitalevna ${ }^{1}$ \\ ${ }^{1}$ Department of Civil Law and Procedure and International Private Law, Peoples' Friendship University of Russia \\ (RUDN University), Moscow, Russia \\ ${ }^{2}$ Department of Theory and History of State and Law, Far Eastern Federal University, Vladivostok, Russia \\ ${ }^{3}$ Vladivostok state University of Economics and service, Vladivostok, Russia \\ Correspondence: Frolova Evgenia Evgenevna, Department of Civil Law and Procedure and International Private \\ Law, Peoples' Friendship University of Russia (RUDN University), Moscow, Russia. E-mail: frolova-ee@rudn.ru
}

Received: June 2, 2020

doi:10.5539/jpl.v13n3p280
Accepted: August 4, $2020 \quad$ Online Published: August 30, 2020

URL: https://doi.org/10.5539/jpl.v13n3p280

This work was financially supported by the Grant of the President of the Russian Federation No. HU-2668-2020.6 National-Cultural and Digital Trends in the Socio-Economic, Political and Legal Development of the Russian Federation in the 21st Century."

\begin{abstract}
The authors investigate an issue of the appearance of new trends in developing alternative ways to resolve financial disputes. It has been found that: 1) selection of an arbitration forum for dispute resolution in the field of international finance instead of national courts of London and New York became an obvious reality that should be taken into account by politicians and entrepreneurs; 2) advantages and disadvantages of arbitration resolution of financial disputes are also obvious, so special attention should be paid to the new forms of dispute resolution clauses - hybrid dispute resolution clauses that authorize counterparties to select between the national judicial proceeding and the international arbitration, allowing the parties to select the most appropriate proceeding jurisdiction as following from the specific dispute based on advantages of both forums; 3 ) in connection with the popularization of alternative ways of dispute resolution in the field of financial relations it is prospective to use mediation for dispute resolution: the entry of Singapore Convention on Mediation 2019 into legal force and joining of global financial leading states to it can contribute to this; 4) in connection with the specifics of cross-boundary financial relations, and for dispute resolution, standard arbitration regulations are not always applicable, so now arbitration institutions tend to follow the way of including separate regulations with regard $\mathrm{f}$ the specifics of these disputes; the latest trend can be considered the creation of separate centres in the field of financial dispute resolution.
\end{abstract}

Keywords: international arbitration, convention on mediation, financial disputes, financial arbitration, hybrid dispute resolution clauses

\section{Introduction}

In the field of the financial service industry, the arbitration and mediation dispute resolution gains popularity as an alternative to the court proceeding due to the number of advantages including the ability of the parties to appoint arbiters with the experience and knowledge in the field of the specific branch of industry or services, the possibility to save confidential information for trade purposes, and flexibility in terms of the procedure, and the enforcement of decisions. In 2018, the McGuireWoods arbitration group specialists noted the sharp increase of international arbitration cases in the largest arbitration centres due to the increase in number of bank, financial, and energy disputes ${ }^{1}$. According to statistical data for 2019, the flow of financial disputes transferred for permission to arbitration keeps increasing, which is explained by the continuously growing volume of bank and financial claims.

\footnotetext{
${ }^{1}$ Deutsch R., Potter F. (2019). Banking and Finance Disputes Drive Record International Arbitration Caseloads//McGuireWoods. July 22, 2019. [Electronic resource]. Access mode: URL: https://www.mcguirewoods.com/client-resources/Alerts/2019/7/banking-and-financedisputes-drive-record-international-arbitration-caseloads Date of access 24.11.2019.
} 
As the number of international transactions in the bank and financial sector increases, the advantages of international arbitration compared to dispute resolution in national courts become more and more obvious for potential users.

Until recently, representatives of the bank and financial sectors traditionally went to courts for dispute resolution. However, recent polls of bank and financial service users show that these users prefer international arbitration in their international transactions. It is proven by the data of the international study of international arbitration evolution issues carried out in 2018. Queen Mary University of London in partnership with White \& Case LLP². $\mathrm{Al}$ the aforementioned is proved by statistical data of leading world arbitration centres for 2018 .

London: In its report of 2018, London Court of International Arbitration (LCIA) demonstrated that 317 arbitration cases in total were delivered to LCIA. In particular, it was noted in the LCIA report that in 2018, the number of disputes in the bank and financial sector increased considerably which confirms the position of LCIA as the main arbitration institution in the world for solving complicated financial disputes. Digits presented in the LCIA report for 2018 also prove the increasing number of appeals to the Emergency Arbitrator and accelerated procedures of the arbitration tribunal formation ${ }^{3}$.

Paris: In 2018 ICC International Court of Arbitration (ICC) considered 842 cases, which is the second-largest indicator of registered cases in history, according to the latest data published by $\mathrm{ICC}^{4}$.

Stockholm: Arbitration Institute of the Stockholm Chamber of Commerce (SCC) submitted the report for 2018 where it stated the unprecedented increase of the dispute average value. It was expressed by the fact that total value of disputes under all cases initiated in 2018 amounted to 13,3 bln EUR (compared to 1,5 bln EUR в 2017) despite the certain decrease of the number of cases submitted. In total, 152 cases were registered ${ }^{5}$.

New York: In 2018, American Arbitration Association and International Centre for Dispute Resolution (AAAICDR), the largest alternative institute for dispute resolution in the USA, provided conflict management and dispute resolutions services under 8983 cases with total claims of 15,6 bln USD. USA. The biggest growth of the number of disputes including resolution of financial disputes - 78\%, was observed (compared to 2017) . $^{6}$

ICSID, the International Centre for Settlement of Investment Disputes, stated in January 2019 that the demand for ICSID services for settlement of disputes continued growing in 2018 with the record number of 56 new registered cases. The indicator of 2018 bit the record of 2017 in 53 registered cases. In total, only 706 cases were registered in ICSID since the first case registered in $1972^{7}$.

\section{Researching Views and Legal Basics of Regulation}

The scientific basis of this paper was formed on the basis of scientific works of scientists Dudin, M.N., Delaney J., Deutsch R., Potter F., Ermakova E., Foo Y., Freeman J., Fisher L., Frolova E., Giaretta B., Cummins T., Lim S., Mrad A., Saunders M., Xin Z., Wong C.

In this paper, the authors have studied and analyzed provisions of international acts - United Nations Convention on International Settlement Agreements Resulting from Mediation ${ }^{8}$ (the "Singapore Convention on Mediation"), statistical reports, and other documents (Queen Mary University of London 2018 International Arbitration Survey on the Evolution of International Arbitration; ICSID Releases 2018 Caseload Statistics; LCIA releases 2018 Annual Casework Report; 2018 B2B Case Statistics Demonstrate Expertise of AAA-ICDR; Court of Arbitration of the International Chamber of Commerce in 2018; The ISDA 2018 Arbitration Guide'; Report by a Task Force

\footnotetext{
2 Arbitration Survey (2018) Queen Mary University of London 2018 International Arbitration Survey on the Evolution of International Arbitration. [Electronic resource]. Access mode: URL: http://www.arbitration.qmul.ac.uk/research/2018/_Date of access 22.11.2019.

${ }^{3}$ LCIA (2018). LCIA releases 2018 Annual Casework Report. [Electronic resource]. Access mode: URL: https://www.lcia.org/News/2018annual-casework-report.aspx Date of access 22.10.2019.

${ }^{4}$ ICC (2018). Court of Arbitration of the International Chamber of Commerce in 2018. [Electronic resource]. Access mode: URL: https:/iccwbo.org/media-wall/news-speeches/icc-arbitration-figures-reveal-new-record-cases-awards-2018/ Date of access 22.11.2019.

${ }_{5}^{5}$ SCC (2018). SCC STATISTICS 2018. The Arbitration Institute of the Stockholm Chamber of Commerce (SCC). [Electronic resource]. Access mode: URL: https://sccinstitute.com/statistics/ Date of access 22.11.2019.

6 AAA (2019). 2018 B2B Case Statistics Demonstrate Expertise of AAA-ICDR. [Electronic resource]. Access mode: URL: https://www.adr.org/sites/default/files/document_repository/190215_AAA_2018_B2B_Stats_Release.pdf Date of access 22.10.2019.

7 ICSID (2018). ICSID Releases 2018 Caseload Statistics. [Electronic resource]. Access mode: URL: https://icsid.worldbank.org/en/Pages/News.aspx?CID=314 Date of access 22.11.2019.

${ }^{8}$ United Nations Convention on International Settlement Agreements Resulting from Mediation (New York, 2018) (the "Singapore Convention on Mediation"). [Electronic Access mode: https://uncitral.un.org/en/texts/mediation/conventions/international_settlement_agreements Accessed 28.11.2019.

${ }^{9}$ ISDA (2018). ISDA Publishes 2018 Arbitration Guide. [Electronic resource]. Access mode: URL: https://www.isda.org/2018/12/17/isda-
} 
of the Commission on Arbitration and ADR of the International Chamber of Commerce (ICC) (2017)).

The scientific development of the content of this scientific research is carried out on the basis of the general scientific method of historical materialism. General scientific methods of cognition are used: dialectical, hypothetical-deductive method, generalization, induction and deduction, analysis and synthesis, empirical description. The study also used private science methods: juridical-dogmatic, statistical method, method of comparative legal analysis, other.

\section{Main Part Creation of New International Centres for Financial Dispute Resolution}

International financial organizations encourage financial institutions to use arbitration in financial dispute resolution.

Research of the Target Group of the International Chamber of Commerce (ICC) Commission on Arbitration and Alternative Dispute Resolution: The increasing complexity and even sophistication of financial markets and financial products, and lessons learned from the financial crisis of 2008, required more complex methods of dispute resolution at the bank and financial transactions. Report of the Target Group of the International Chamber of Commerce (ICC) Commission on Arbitration and Alternative Dispute Resolution proved that financial institutions of the world do not use the potential benefits of the international trade and investment arbitration to the highest extent possible ${ }^{10}$. The report stated that the Target Group considered the wide range of bank and financial activity regardless of the fact whether it was carried out by licensed banks or funds. The Target Group completed an analysis of the huge line of arbitration decisions under-investment disputes. It was noted that these solutions open wide possibilities concerning contractual requirements that can serve as catalysts on sensitivity of the bank and financial sectors to arbitration in the whole ${ }^{11}$.

The 2018 ISDA Arbitration Guide: in September 2013 International Swaps and Derivatives Association published The 2013 ISDA Arbitration Guide ${ }^{12}$ for arbitration use in typical contracts. The origins of the specified document appearance were in the growing use and interest in arbitration for dispute resolution in transactions with derivatives. It should be noted that historically parties of financial disputes on swaps and derivatives markets, as a rule, preferred settling their disputes in state courts, not through arbitration. This preference is reflected in Guide for Dispute Resolution arising from standard financial agreements published by ISDA in 2002 and 1992 that provided for the jurisdiction of English or new York courts ${ }^{13}$.

In 2018 (5 years after the first edition), the new Arbitration Guide, the 2018 ISDA Arbitration Guide, was issued. The 2018 Guide contains the line of new typical dispute resolution clauses under various financial contracts. Basic structure of the first ISDA Guide edition remained the same in the second edition. The second edition is based on the first edition success and contains the necessary updates because five years passed since the moment of the first edition. It also takes into consideration the changes in market practice for this period. In particular, it takes into regard the fact that the parties of financial contracts consider now the wider scope of regulations than five years ago $^{14}$.

publishes-2018-arbitration-guide/ Date of access 22.11.2019.

10 Report ICC (2017) Report by a Task Force of the Commission on Arbitration and ADR of the International Chamber of Commerce (ICC). [Electronic resource]. Access mode: URL: https://iccwbo.org/publication/financial-institutions-international-arbitration-icc-arbitration-adrcommission-report/ Date of access 03.11.2019.

11 Frolova, E.E., Ermakova, E.P., Protopopova, O.V. (2020) Consumer protection of digital financial services in Russia and abroad. Advances in Intelligent Systems and Computing, 1100 AISC, pp. 76-87;

Ermakova E., Frolova E. et al (2018). Main Components of Protecting Consumers of Financial Products in Asian-Oceanic (APAC) Countries. International Journal of Engineering and Technology (UAE). Vol 7, No 4. P. 157-162;

Ermakova E. P., Frolova E. E. Legal regulation of digital banking in Russia and foreign countries (European Union, USA, China). Bulletin of Perm University. Legal science. 2019. No. 46. Pp. 606-625;

Frolova E., Polyakova, T.A., Dudin, M.N., Rusakova, E.P., Kucherenko, P.A. (2018). Information Security of Russia in the Digital Economy: The Economic and Legal Aspects. Journal of Advanced Research in Law and Economics. vol. 9 (1) P. 89-95;

Miroshnichenko O.I., Samusenko T.M., Gaivoronskaya Ya.V., Frolova E.E. Doctrine in the modern world: legal traditions and modern potential The Social Sciences (Pakistan). 2018. vol. 13. № 2. p. 235-240.

12 The 2013 ISDA Arbitration Guide. [Electronic resource]. Access mode: http://www.isda.org/publications/pdf/ISDA_Arbitration_Guide_Final_09.09.13.pdf Date of access 03.12.2019.

13 Freeman J., Fisher L. (2018). The rise and rise of Arbitration in banking and finance disputes// Allen \& Overy. 09 February 2018. [Electronic resource]. Access mode: URL: http://www.allenovery.com/publications/en-gb/Pages/The-rise-and-rise-of-Arbitration-in-banking-and-financedisputes.aspx Date of access 22.11.2019.

14 Frolova E., Polyakova, T.A., Dudin, M.N., Rusakova, E.P., Kucherenko, P.A. (2018). Information Security of Russia in the Digital Economy: The Economic and Legal Aspects. Journal of Advanced Research in Law and Economics. vol. 9 (1) P. 89-95. 
The 2013 ISDA Guide contained clauses of the following recommended arbitration centres: London (LCIA), New York (AAA-ICDR), Paris (ICC), Hong Kong (HKIAC), Singapore (SIAC), The Hague (P.R.I.M.E. Finance). The second edition of 2018 ISDA Guide contains four additional typical provisions for the use in financial contracts: Stockholm (SCC); Frankfurt (DIS); Dubai (DIFC-LCIA), and Vienna (VIAC).

P.R.I.M.E Finance: in January 2012, the first international financial arbitrage in the world, Centre for International Financial Dispute Resolution - P.R.I.M.E Finance - was created in The Hague. The Centre offers arbitration, negotiation, and other services for dispute resolution in the financial sector. The Centre has its own rules of arbitration and its own team of experts and arbiters containing the representatives of American, European, and Asian markets ${ }^{15}$. Rules of Arbitration of P.R.I.M.E. Finance Centre differs from the other rules of arbitration due to the fact that arbitration decisions can be given publicity upon consent of all parties to a dispute. The Centre administration can also publish the decision in full volume and anonymously, if the parties did not object to the publication during one month after the decision receipt. These provisions of the Rules are aimed at the support of the common goal of P.R.I.M.E. Finance Centre, namely: to increase the juridical security by creating a considerable number of arbitration decisions (precedents) in the field of complex financial products. However, the specified feature of the Rules undermines one of the qualitative characteristics of the international trade arbitration, confidentiality.

Specialized financial dispute panels (Hong Kong experience): Traditional centres of international trade arbitration responded to the creation of specialized financial arbitration in the Hague with their own innovations in the field of the arbitration proceeding. For example, in May 2018, The Hong Kong International Arbitration Centre (HKIAC) informed about the creation of the Panel of Arbiters for financial services, including leading world experts in the field of arbitration (so far, 30 arbiters from 17 countries of the world) ${ }^{16}$. Due to the opening of a new specialized panel, the HKIAC Centre was nominated for "the best innovations" in the 2019 GAR Awards rating ${ }^{17}$.

Every year, HKIAC considers numerous inquiries related to financial services with the participation of large banks and funds. The experience of HKIAC in this field was recognized by the line of professional international institutions. In September 2013 The HKIAC Centre dispute resolution clause was included into 2013 ISDA Arbitration Guide as a recommended clause. In September 2016, Financial Sector Branch of the London Arbitration Club included HKIAC as the recommended arbitration institution into its procedure of accelerated arbitration for financial services. In October 2016, the Report of the Target Group of the International Chamber of Commerce (ICC) Commission on Arbitration and Alternative Dispute Resolution determined the HKIAC Centre as one of the arbitration institutions, the most often selected by financial institutions.

\subsection{Hybrid Jurisdictional Clauses}

International arbitration is the most logical mechanism for dispute resolution at an international bank and financial operations ${ }^{18}$. Besides providing efficient means for dispute resolution, it can serve a tool of risk reduction for reacting to the uncertainty of today's global business environment ${ }^{19}$. However, dispute resolution by arbitration has its serious disadvantages as well. First of all, they include: 1) high arbitration cost; 2) long dispute consideration terms; 3 ) impossibility to consolidate the existing arbitration proceedings contrary to the national court; 4) absence of obligatory precedents formulated in the arbitration decision contrary to the national court; 5) impossibility of the final decision appealing, etc. ${ }^{20}$

With the purpose to combine the advantages of the arbitration and the national judicial proceeding, many specialists now advise the parties to financial disputes to use hybrid clauses. For example, the 2013 ISDA Arbitration Guide contained a recommendation on the use of hybrid dispute resolution clauses. In addition, it

\footnotetext{
${ }^{15}$ Giaretta B., Cummins T. (2017). Use of arbitration in financial transactions// QUICKGUIDES 09 JAN 2017. [Electronic resource]. Access mode: URL: https://www.ashurst.com/en/news-and-insights/legal-updates/quickguide---use-of-arbitration-in-financial-transactions/ Date of access 20.11.2019.

${ }^{16}$ Xin Z. (2018). HKIAC launches Panel of Arbitrators for Financial Services// HKIAC. 10 May 2018. [Electronic resource]. Access mode: URL: https://www.hkiac.org/news/hkiac-launches-panel-arbitrators-financial-services-disputes Date of access 21.11.2019.

${ }^{17}$ Lim S. (2019). Innovating the Future: Recent Changes and Developments in Global and Regional Arbitral Institutions// Global Arbitration Review. The Asia-Pacific Arbitration Review 2020. 11 June 2019. [Electronic resource]. Access mode: URL: https://globalarbitrationreview.com/b Date of access 21.11.2019.

${ }^{18}$ Dudin, M.N., Sekerin, V.D., Smirnova, O.O., Frolova, E.E., Sepiashvili, E.N. (2014) State anti-crisis management of banking sector: Looking for optimization ways and contemporary development trends. Journal of Advanced Research in Law and Economics, 5(2), pp. 74-81

${ }^{19}$ Deutsch R., Potter F. (2019). Op.cit.

${ }^{20}$ Saunders M. et al. (2019). Use of arbitration in finance disputes//Ashurst. June 21, 2019. [Electronic resource]. Access mode: URL: https://www.ashurst.com/en/news-and-insights/legal-updates/quickguide---use-of-arbitration-in-financial-transactions/ Date of access 23.10.2019.
} 
should be taken into account that after the 2008 global financial crisis, the financial market players focused on provisions of dispute resolution in their financial operations, with the purpose to provide a more efficient implementation of their contractual rights in relation to debtors that do not fulfil their obligations. As a result, hybrid arbitration clauses became more frequent in such operations, especially in credit agreements ${ }^{21}$.

Hybrid jurisdiction clause enables a party to deliver disputes by condition as of the day they arise, either to the arbitration or to the court process. The term "split" or "hybrid" clauses covers various provisions on "hybrid dispute resolution clauses", the most common of which is a provision that provides both for court jurisdiction and arbitration in combination with a mechanism allowing one or both parties to determine the specific procedures from the moment of origin of a dispute. As a rule, these provisions are used when one of the parties - as a rule, a bank - has a stronger position at negotiations. These clauses authorize the bank to select between the national judicial proceeding and the international arbitration. For example, this clause could provide for the dispute resolution in the High Court of England, but the bank is also allowed to select another way to deliver the dispute under consideration to the international arbitration ${ }^{22}$.

Hybrid clauses, combining two or more ways of dispute resolution, have always existed. However, they became more actual in connection with the introduction of mediation, that can exist in various combinations, into the legislation and the national practice. The use of hybrid clauses by the financial dispute parties can increase sharply upon coming into force of Singapore Convention on Mediation 2019, the purpose of which is creating the unified and efficient structure of fulfilment of mediation settlements at the international level.

\subsection{Regularization of Mediation Decisions Execution at the International Level - Singapore Convention on Mediation 2019}

United Nations Convention on International Settlement Agreements Resulting from Mediation (Singapore Convention on Mediation) was signed in Singapore on August 7, 2019. The text of the Convention was adopted in New York on December 20, 2018, and on August 7, 2019, the Convention was signed by 46 states, including the USA, Singapore, China, India, Malaysia, the Philippines, and South Korea. Russia has not yest signed the text of the Convention. In August 2019, the Convention was signed by 5 more countries, and 20 more states expressed their intention to sign it. The Convention will come into force 6 months after 3 states ratify it. For the time being, mediation agreements on mediation that are the result of mediation negotiations, at least, between two parties in a dispute cannot be enforced in a different country. It is expected that courts of the states that signed the Convention will consider applications of the parties, either for providing the execution of such agreements for dispute settlement or for enabling parties to refer to the agreement with the purpose to prove that the issue has already been resolved ${ }^{23}$.

Art. 1 of the Convention specifies that it applies to international settlements reached due to mediation and executed by the parties in writing with the purpose to settle the trade dispute. Settlements executed by the consumer for personal, family, or home purposes, or those relating to family, succession, or labour legislation, were excluded from the Convention jurisdiction.

Advantages of Singapore Convention (2019): The Convention can considerably change the perception of mediation by making it one of the most sought-after methods of settling cross-boundary trade disputes. The advantage of joining states to the Convention is the fact that this document form will allow creating the unified mediation mandatory for all the member states. As a rule, scientists and practitioners determine the following key aspects of the Singapore Convention on Mediation 2019: a) compulsory enforcement of mediation settlements; b) public awareness-raising in relation to mediation; c) wider application of mediation at the international level ${ }^{24}$. Thus, with the growth of international trade and projects where versatile participation all over the world is observed,

\footnotetext{
${ }^{21}$ Mrad A. (2016) International Overview of Hybrid Arbitration Clauses In Financial Transactions: Challenges And Practical Solutions [Electronic resource]. Access mode: URL: https://www.eptalex.com/wp-content/uploads/2016/12/Hybrid-Arbitration-Clauses-by-AnthonyMrad.pdf Accessed 12.11.2019.

22 Saunders M. et al. (2019). Op.cit.

${ }^{23}$ Wong C. (2019). 46 countries sign international mediation treaty named after Singapore// SPH Digital News. AUG 7, 2019. [Electronic resource]. Access mode: URL: https://www.straitstimes.com/singapore/key-facts-about-the-singapore-convention-on-mediation Date of access 03.12.2019.

${ }^{24}$ Foo Y. (2019) Singapore Convention on Mediation 2019: Embarking on a new era in alternative dispute resolution//Mediation in Today's News - Mediate.com. [Electronic resource]. Access mode: URL: https://www.clydeco.com/insight/article/singapore-convention-on-mediation2019-embarking-on-a-new-era-in-alternativ? Date of access 23.11.2019;
}

Delaney J. (2019). Singapore Mediation Convention. 08 August 2019. [Electronic resource]. Access mode: URL: https://www.bakermckenzie.com/en/insight/publications/2019/08/singapore-mediation-convention Date of access 22.11.2019. 
Singapore Convention on Mediation is timely to increase trust to mediation in terms of provision of the fulfillment of mediation settlements. However, this is possible only in the case when the number of Convention member states will increase to a considerable number. Convention on Mediation was promoted as an equivalent of the wellknown New York Convention on the Recognition and Enforcement of Foreign Arbitral Awards. Due to this, it should be expected in the nearest future that the Convention will be able to change the approach to mediation as the new means of global dispute resolution.

\section{Conclusion}

Based on the study, the authors came to the following conclusions:

1) selection of an arbitration forum for dispute resolution in the field of international finance instead of national courts of London and New York became an obvious reality, that should be taken into account by politicians and entrepreneurs;

2) advantages and disadvantages of arbitration resolution of financial disputes are also obvious, so special attention should be paid to the new forms of dispute resolution clauses - hybrid dispute resolution clauses (hybrid dispute resolution clauses) that authorize counterparties to select between the national judicial proceeding and the international arbitration allowing the parties to select the most appropriate proceeding jurisdiction as following from the specific dispute, based on advantages of both forums;

3 ) in connection with the popularization of alternative ways of dispute resolution in the field of financial relations, it is prospective to use mediation for dispute resolution: the entry of Singapore Convention on Mediation 2019 into legal force and joining of global financial leading states to it can contribute to this.

4) in connection with the specifics of cross-boundary financial relations and for dispute resolution, standard arbitration regulations are not always applicable, so now arbitration institutions tend to follow the way of including separate regulations with regard to the specifics of these disputes; the latest trend can be considered the creation of separate centres in the field of financial dispute resolution.

\section{Copyrights}

Copyright for this article is retained by the author(s), with first publication rights granted to the journal.

This is an open-access article distributed under the terms and conditions of the Creative Commons Attribution license (http://creativecommons.org/licenses/by/4.0/). 